\title{
A CRITICAL REFLECTION ON THE SOUTH AFRICAN LAW OF THE CHILD
}

\section{Introduction}

Children are considered to be vulnerable, and therefore need to be protected against parents, strangers and even themselves (Boezaart Child Law in South Africa (2009) 247). As a consequence, the State's quest for the protection of children in South Africa is expressed in the implementation of legislation designed to offer greater care and protection. For instance, section 28 of the Constitution of the Republic of South Africa, 1996 (hereinafter "the Constitution"), offers a wide range of rights which are designed to offer greater protection to children. The rights of children can, in effect, be categorized into two themes. The first relates to the protection of children - as the child is dependent on those around him or her due to a lack of capacity, and is therefore vulnerable (Boezaart Child Law in South Africa 275). The second theme relates to the autonomy of children (Boezaart Child Law in South Africa 275).

Section 28(2) of the Constitution provides that in any matter concerning a child, the best interests of the child are of paramount importance. However, most South African legislative provisions that deal with minor children seem to miss this principle, and are riddled with inconsistencies. In many statutes, where the principle is recognized, there is either limited appreciation of the significance of the principle and its overall impact on issues concerning children, or there is no coherence with the manner the courts have interpreted and applied the principle. For example, the recent judgment of the Teddy Bear Clinic case ([t]he Teddy Bear Clinic for Abused Children \& RAPCAN v Minister of Justice and Constitutional Development \& National Director Public Prosecutions [The Trustees for the Time Being of the Women's Legal Centre Trust, Tshwaranang Legal: Advocacy Centre \& Justice Alliance of South Africa intervening as Amici Curiae] (73300/10) [2013] ZAGPPHC 1) declared sections 15 and 16 of the Criminal Law (Sexual Offences and Related Matters) Amendment Act (32 of 2007, hereinafter "the Sexual Offences Act") unconstitutional. The judgment has been heavily criticized by different segments of society for encouraging teens to engage in wanton sexual intercourse, but illustrates some of the flaws in legislation aimed at protecting the welfare of minor children in South Africa. Furthermore, the common law and other legislation such as the Choice on Termination of Pregnancy Act (92 of 1996, hereinafter "the Choice Act"), the Marriage Act (25 of 1961, hereinafter "the Marriage Act"), and provisions of the Children's Act (38 of 2005, hereinafter "the Children's Act") regulating contraceptives and condoms, all contain such inconsistencies. For instance, the common law and section 24 (together with $s$ 26) of the Marriage Act allow a minor from the age of puberty to enter into a valid marriage; section 129 of the Children's Act requires that a minor aged 
twelve be assisted by a guardian to undergo a surgical operation; whereas sections of the Choice Act do not require parental consent for terminating a minor's pregnancy.

This note reviews the above and other inconsistences currently prevalent in the law of the child in South Africa. A brief overview of the Teddy Bear Clinic case will be considered. Thereafter, it outlines and examines various gender-based contradictions in the law, and examines the possible rationale for justifying the particular legislative measure concerned. The note concludes by proposing possible solutions to the discrepancies that have been identified.

\section{The Teddy Bear Clinic judgment}

An application was brought before the North Gauteng High Court challenging the constitutional validity of sections 15,16 and 56 (2) of the Sexual Offences Act. These provisions criminalize numerous consensual sexual activities between children of a certain age. The applicants argued this provision was unconstitutional as they infringed on a child's right to dignity and privacy. Section 15(1) provides that any person who commits an act of sexual penetration with a child, even with the consent of the child, shall be guilty of an offence. This applies notwithstanding the fact that both parties were children at the time of the alleged offence. The applicants argued that the criminalization of consensual sexual acts between adolescents (aged 12-15 years) was unconstitutional, as it violated many of their rights (Teddy Bear Clinic par 32). They also argued that criminalizing consensual sexual acts between an adolescent and another child, who is sixteen or seventeen years of age, violates the "same rights in cases where the adolescent is two years or less younger than the older child" (Teddy Bear Clinic par 32). Section 16(1), on the other hand, provides that a person who commits an act of sexual violation against a child (even with the consent of the child) shall be guilty of a sexual violation. In terms of this section, both parties must be charged for the contravention of section 16 of the Sexual Offences Act (s 16(2)). Any person charged with contravening section 16, may raise the defence in section 56(2) of the Act, namely that both the accused persons were children and the age difference between them was not more than two years at the time of the alleged commission of the offence. In respect of both sections 15 and 16, the National Director of Public Prosecutions must authorize the prosecution of both parties in writing. The Minister of Justice and Constitutional Development and the National Director of Public Prosecutions opposed the application to declare the impugned sections unconstitutional. However, the High Court upheld the application. In this ruling, Judge Rabie declared sections 15 and 16 invalid, and deemed them to be inconsistent with the Constitution, for two reasons: the criminalizing of consensual sexual penetration of children aged 12-16 years, and of the consensual sexual penetration between a child aged 1618 years and a child who is younger than 16 years of age and not more than two years younger than the other child. The court held that sections 15 and 16 should instead be interpreted to imply that an adult (a person aged 18 years and older) who engages in consensual sexual acts with a child aged 12-15 years, will be guilty of the offence of statutory rape (Teddy Bear Clinic 
par 22). In the case of consensual sexual activity between (a) a child aged 16-18 years and a child aged 12-15 years, or (b) two children aged 12-15 years, the court stated that the provisions of the two sections should only apply if the age difference is more than two years (Teddy Bear Clinic pars 23.1 and 23.2).

Judge Rabie then made an order amending sections 15 and 16 of the Sexual Offences Act to reflect his findings, which had to be confirmed by the Constitutional Court in terms of section 172(2) of the Constitution (Teddy Bear Clinic par 107 and 123). Effectively this means that where only minors are concerned, consent to sexual intercourse can be given from age 12 onwards, provided the older child is not more than two years older than the consenting younger child. However, any adult who has sexual intercourse (including oral sex), with a child under the age of 16 years, even with the consent of the minor, will be committing statutory rape, or sexual assault (where there was no penetration). However, the common law and the Marriage Act, allow a girl who is 12 years or older, and a boy who is 14 years or older to marry, provided that the parents or a guardian, and (where legally necessary) the Minister of Home Affairs, give their consent to such a marriage (s 24 and 26 of the Marriage Act).

The Constitutional Court has to a large extent confirmed the judgment of the High Court late in 2013 (2013 (12) BCLR 1429 (CC); 2014 (2) SA 168 (CC)). Confining its judgment to adolescents, it held that sections 15 and 16 of the Sexual Offences Act violated their rights of dignity and privacy inherent in the principle of the best interests of the child (par 79). The authors submit that more complexities and inconsistencies are likely to emerge as a result of the ruling. It should not be a case of with whom a minor child is allowed to engage in sexual activity, but rather whether such a minor is allowed to engage in sexual activity in the first place.

\section{The legal age to conclude a marriage}

In terms of common law, puberty, which is 12 years for girls and 14 for boys, is the legal age for concluding a valid marriage (Barratt "Minority: How Age Affects Status and Capacity" and "Requirements for Civil Marriage" in Barratt and Domingo (eds) Law of Persons and the Family (2012) 63 and 234). Therefore, in terms of section 24 of the Marriage Act, a minor child who has attained puberty may get married, provided the necessary consent of a parent or guardian (also confirmed by s 18(3)(c) of the Children's Act) is obtained. Moreover, girls and boys below the ages of 15 and 18 years, respectively, must obtain the written consent of the Minister of Home Affairs and parental consent (s 26(1) of the Marriage Act). It appears that the ages referred to were determined based on the biological fact that girls reach puberty at the age of 12 years, whilst boys reach puberty at the age of 14 years.

Determining the age of consent on the basis of puberty is problematic, as it assumes emotional maturity at puberty. In our view, neither girls nor boys are emotionally or physically fully mature at this age. Furthermore, there does not seem to be established scientific and objective evidence to support the view that girls attain emotional maturity earlier than boys (see, eg, 
Harder "The Developmental Stages of Erik Erikson" http://www.support4 change. $\mathrm{com} /$ index.php?view=article\&catid=35\%3Awho-youre \&id=47\%3Aer ik-eriksonsdevelopmentalstages\&format=pdf\&option=com_content\&ltemid= 08 accessed 2013-07-29). The authors submit that, biologically, puberty is only indicative of sexual maturity, and not emotional maturity. The differentiation in ages inadvertently discriminates unfairly against minor girls, as they would be exposed to marriage earlier than boys, usually with older men. Also, one wonders why boys would need the consent of the Minister of Home Affairs until they are 18, and yet girls only require it until they have reached the age of 15 years. This is also inconsistent with the fact that parental consent is needed for both girls and boys until they are aged 18 years. The assumed stage of maturity for boys and girls is also controverted by section 17 of the Children's Act, which sets the age of majority at eighteen years for both boys and girls. The authors submit that girls are more in need of special protection than boys, as experience suggests that girls are more vulnerable to sexual exploitation than boys, and thus the age discrepancy is devoid of rationale. For example, there have been numerous media reports of young girls being abducted into forced marriages with the knowledge of their parents (see, eg, "The Right to Cultural Freedom and Forced Marriages in SA: What the Constitution Giveth, the Constitution Taketh Away" http://www.polity.org.za/print-version/the-right-to-cultural-free dom-and-forced-marriages-in-sa-what-the-constitution-taketh-away-2013-0213 accessed 2013-07-23; Bhelekhazi "Pama-actionaid" http://www.actionaid. org/south-africa/stories/bhelekhazi-pama accessed 2013-07-23).

The provisions of the Marriage Act pertaining to a child's consent to civil marriage are also belied by the provisions of the Recognition of Customary Marriages Act (120 of 1998, hereinafter "the Customary Marriages Act"). Section 3(1)(a)(i) of the Customary Marriages Act provides that "prospective spouses to a customary marriage must both be above the age of 18 years" for it to be valid, unless the Minister of Home Affairs gives written permission to a person under the age of 18 years to enter into the customary marriage. The term "spouses" refers to male and female, and there is thus no differentiation insinuated. Of particular significance is section 3(4) of the Act. This section is similar to section 26(1) of the Marriage Act. However, unlike section 26(1) of the Marriage Act, section 3(4) of the Customary Marriages Act does not make a distinction between minor girls and boys. It merely provides that: "the Minister ... may grant written permission to a person under the age of 18 years to enter into a customary marriage ..." This section does not have different provisions for girls below the age of 15 years and boys below the age of 18 years. Thus, the Customary Marriages Act affords both girls and boys equal protection. There is no rationale, however, for why there should not be similar provisions in the Customary Marriages Act to those that apply in respect of civil marriages. We see no reason for differentiation between customary and civil marriages, as far as children are concerned. When one considers the restriction in respect of customary marriages on one hand, and the relaxation in respect of civil marriages on the other, the law offers protection to minors with the one hand and takes it away with the other.

The Civil Union Act (17 of 2006 hereinafter "the Civil Union Act") only permits persons aged 18 years or older to enter into a civil union (s 1 of the 
Act). One, however, wonders about the reasoning behind this prohibition, especially when one considers that the Marriage Act allows minors from the age of puberty (ages 12 and 14 years), albeit with some conditions, to enter into a civil marriage. It raises many questions. For instance, is it not an indirect way of stating that a civil union is psychologically (or otherwise) harmful to the well-being of a minor? Be that as it may, it is imperative to interrogate the legal implication of this restriction on the child's right to equality in terms of section 9 of the Constitution, especially in light of what Judge Rabie held in Teddy Bear Clinic with regard to the exercising of rights by children (Teddy Bear Clinic par 80 and 82). The court held that children's constitutional rights are not held in abeyance (Teddy Bear Clinic par 75 and 80).

The authors are not in favour of the marriage of minors, in general. However, we argue the issue from the standpoint of the current legal position. In this regard, we opine that minor children are entitled to exercise their rights (including the right to privacy of their intimacy for those at the age of adolescence) in the same way as adults (par 80 and 82). It thus amounts to unfair discrimination for the law not to impose the same restrictions to civil marriages, as it does on civil unions and customary marriages, unless it can be demonstrated that there is a reasonable explanation for such dissimilarity. Hence, we submit that section 3(4) of the Customary Marriages Act exposes the common law, as well as sections 24 and 26 of the Marriage Act, to challenges on their constitutional validity as both the common law and the relevant sections of the Marriage Act amount to indirect discrimination based on culture, age and gender. The same can be said of the Civil Union Act, which allows entry into a civil union only at 18 years of age of both parties without any exception. Looking at the provisions of the Marriages Act vis-á-vis the Civil Union Act, the relevant provisions of the latter amount to unfair differentiation on the basis of sexual orientation. They permit a minor who have reached puberty to marry with consent of parents (and the Minister of Home Affairs, in the case of girls under the age of 15 or boys under the age of 18 years). There is no apparent rationale why two legislation should be different. We thus submit that the differentiation serves no legitimate objective or governmental purpose.

Furthermore, the mentioned provisions of the common law and the Marriage Act are diametrically opposed to the Sexual Offences Act, which expressly prohibits sexual intercourse with a minor child, as discussed above. This would be problematic, as consortium omnis vitae (including sexual intercourse) is an essential aspect of any marriage. One is prompted to wonder if such a marriage is supposed to be celibate. In addition, does the consent of the parents or guardian and that of the Minister of Home Affairs "grant" emotional and/or physical maturity to a minor? While it is true that a minor attains majority upon marriage (Barratt in Barratt and Domingo (eds) Law of Persons and the Family 76), the question of whether marriage "endows" a minor with the necessary maturity to govern his affairs, also begs an answer. This is a glaring inconsistency in our law. Therefore, we also submit that the logic of allowing a child under 16 years of age to marry is dubious. In our opinion, the removal of restrictions does not serve the interests of the minor child. Instead, they serve petty patriarchal interests. The issue is especially concerning, as in most cases it is girls who will be 
exposed to this danger of exploitation. This amounts to indirect discrimination against girls which is neither fair nor rational. Again, we submit that the law here offers protection with one hand, and takes it away with the other.

\section{$4 \quad$ Criminal and delictual capacity}

In terms of section 7(1) of the Child Justice Act (75 of 2008, hereinafter "the Child Justice Act") "[a] child who commits an offence while under the age of ten years does not have criminal capacity and cannot be prosecuted for that offence ..." Instead, this Act which came into effect on 1 April 2010, requires that such a child should not be arrested, but should rather be handed over immediately to his/her respective parents or an appropriate adult or a guardian (s 9). This effectively amends the common-law position where the minimum age of criminal capacity was seven years (s 11(3)). The minimum age of criminal responsibility will only be reviewed by the Minister of Justice and Constitutional Development after five years from the date of it coming into effect (s 8). However, in terms of section 7(2) of the Act, a child offender between the age of ten and fourteen years is rebuttably presumed to lack criminal capacity. The onus is on the State to prove beyond reasonable doubt that such a minor has criminal capacity, in accordance with the process provided for in section 11 of the Act.

On the other hand, the common law still applies in respect of delictual accountability. In terms of the common law, the age of seven years remains as the age of absolute immunity that is, anyone seven years or younger is irrebuttably culpa incapax. Effectively this means that a minor who is, for instance, nine years old will be exposed to delictual proceedings, while he or she is shielded from criminal liability. While one understands the seriousness of the situation if a child is found guilty of a criminal offence, the delictual liability is grave, nonetheless. As in criminal proceedings, such a minor may be psychologically traumatized by a trial. In our view, in light of section 9 of the Constitution, there is no sound reason for such a differentiation. The authors submit that the legal age for immunity should be set at ten years for both criminal and delictual accountability.

Moreover, the common law sets the age limit from which a minor child is rebuttably presumed to lack delictual capacity, from the age of seven to the age of puberty. For criminal liability, the corresponding age limit for rebuttable incapacity is set at 14 years by the Child Justice Act (s 11(1) and 11(2)). This is problematic for two reasons. Firstly, the age limit for criminal liability is not in line with that of delictual liability, as puberty occurs at the age of on the average 12 and 14 years for girls and boys respectively. The authors submit that the delictual-liability position amounts to unfair differentiation in respect of girls who are in effect exposed to liability earlier, this liability based purely on their gender. Secondly, setting the age limit at the age of puberty is problematic as it equates procreational readiness with mental maturity. Under delictual liability, the Child Justice Act does not discriminate on the basis of gender. However, this is not to say that we endorse the criminal-law position in respect of the age limit of 14 years. In our view, there is no reason why this limit should not be set at 16 years for both criminal and delictual accountability, the same age as for sexual 
consent. In which case then, the age at which accountability is presumed, may be shifted to the age of 16 or older, instead of the current age of 14 and older, for both criminal and delictual liability. The authors argue that sixteen is the preferred age as it is the highest age at which the law requires children to be matured, albeit for sexual consent. This will harmonise the South African law regulating the capacity of children, both statute and common law. It will also eliminate gender-based capacity in respect of children. It is also submitted that at the age of 16 years, children will be better matured to understand the implications and consequences of their conduct, both criminally and in delict.

\section{Unassisted contracts and litigation}

Under the common law, an unassisted contract of a minor is of no force (a naturalis obligatio), unless the minor only derives rights without acquiring obligations. The minor's guardian is the one who is left with the option to ratify the unassisted agreement or not (Barratt in Barratt and Domingo (eds) Law of Persons and the Family 41). However, in respect of their capacity to litigate, a minor below the age of seven years has no capacity to do so, while those above the age of seven years have limited capacity to litigate and must be assisted by a parent or a guardian. Any litigation conducted by an unassisted seven-year-old minor is void (see, Yu Kwam v President Insurance Co Ltd 1963 (1) SA 66 (T); Barratt in Barratt and Domingo (eds) Law of Persons and the Family 71; Boezaart and De Bruin "Section 14 of the Children's Act 38 of 2005 and the Child's Capacity to Litigate" 20112 De Jure 417-419; and Boezaart Law of Persons 5ed (2010) 90). Therefore the current position on minors' unassisted litigation creates an inconsistency with the position taken by the courts and that of the common law under contract. As authors like Boezaart argue, there is no reason why the law would not apply similar standards and recognize any judgment in favour of a minor as valid and enforceable (Boezaart Law of Persons 90). This could be done at the discretion of the High Court, as the upper guardian of all minor children. Alternatively, it may be left to the discretion of the guardian, as is the position with a naturalis obligationis.

\section{$6 \quad$ Health and other health-related matters}

Section 13(1) of the Children's Act provides that every child is entitled to have access to information on health promotion, the prevention and treatment of ill-health and disease, sexuality and reproduction, and health status. Section 134 also provides that a child aged 12 years may have access to condoms and other contraceptives. However, it is unknown what those contraceptives could be used for, given that the law prohibits minors of this age from engaging in sexual activity. In the Teddy Bear Clinic, both the High Court (par 76-82) and the Constitutional Court (par 79) ruled that adolescents should be allowed to explore their sexuality.

Section 130 of the Children's Act, in particular, provides that a child may consent to having an HIV test, if aged 12 years of age or older or if such child is under the age of 12 years and is of sufficient maturity to understand the benefits, risks and social implications of such a test. For such testing, 
there has to be pre-test and post-test counselling (s 132). The question, however, remains as to whether a 12-year old child has the mental and/or emotional capacity to fully understand the nature of the medical treatment, in order to consent to it. Despite the debate as about whether a 12-year old child can consent to medical treatment, the purpose and the spirit of the legislation must be considered which is to involve children in decision making regarding their own health (Kling "Ethical Issues in Treating Children" 201124 (4) Current Allergy \& Clinical Immunology 218 219).

The Children's Act has also lowered the age of consent to medical treatment and surgical operations, from 14 and 18 years respectively (previously provided for by s 39(4)(a) and (b) of the Child Care Act 74 of 1983) to 12 years (s 129 of the Children's Act). Section 129 of the Children's Act further provides that a 12-year old can only consent to a surgical operation with the assistance of their parent or guardian. As a prerequisite, a minor of such an age should be sufficiently mature if they were to independently consent to medical treatment without the consent of the parent or guardian (s 129 of the Children's Act). Moreover, section 10 states that "every child that is of such an age, maturity, and stage of development as to be able to participate in any matter concerning that child, has the right to participate in an appropriate way and views expressed by the child must be given due consideration". Additionally, section 31 provides that, depending on their level of maturity, children have to be consulted about major decisions that involve them. These provisions act as a safeguard, so that parents or guardians do not abuse their parental responsibilities. Furthermore, the United Nations Convention on the Rights of the Child, ratified by South Africa, provides that children have the right to express their views freely, and to have such views taken seriously in accordance with their age and maturity (Article 12).

The difficulty that arises, however, is determining whether a child is sufficiently mature to understand and comprehend the nature of medical treatment. Kling (2011 24(4) Current Allergy \& Clinical Immunology 218) suggests that the nature of the decision to be made, reasoning, understanding and voluntariness of the consent, are factors that should be considered when determining the maturity of a child. The nature of the decision being made also depends on the seriousness of "the intervention or treatments (eg, having a blood test compared with major surgery), whether it is an emergency situation, and whether the benefits outweigh the risks and harms" (Kling 2011 24(4) Current Allergy \& Clinical Immunology 219). Voluntariness requires that consent to medical treatment be informed and voluntary, reasoning refers to the requirement that a child should be able to reason logically or make a decision, and understanding relates to the child's knowledge and experience of the problem (Kling 2011 24(4) Current Allergy \& Clinical Immunology 218). The child's ability to reason is influenced by his or her age, intelligence, cognitive functioning and emotional functioning (Kling 2011 24(4) Current Allergy \& Clinical Immunology 218). In this regard, a child aged 12 years is relatively young and immature. Therefore he or she might be unable to fully reason on matters and make an informed decision.

Another concern is the lack of consistency in the above-mentioned provisions. Notwithstanding the dealing with health-related matters, their 
requirements differ materially. For instance, the Children's Act requires that a 12-year old child must be counselled prior to having the HIV test, whereas it is not the case in respect of medical treatment (see $s 129$ and 132). It is also of concern that children 12 years and younger can take an HIV test without the consent of their parents or guardian. It is not immediately apparent why parents would be allowed to be involved in medical treatment, but be excluded in the instance of HIV testing, especially given the risks and social implications associated with being HIV-positive. The same argument applies in respect of excluding parents in matters relating to a child's sexual health (s 134 of the Children's Act). Fear of interference by the parents is not an issue, as the High Court as an upper guardian of all minor children will always overrule unwarranted interference.

\section{$7 \quad$ Minors and the termination of pregnancy}

Sections 5(2) to 5(3) of the Choice Act provide that a female of any age may consent to the termination of a pregnancy. Section $5(1)$ specifically provides that such termination of pregnancy "may only take place with the consent of a pregnant woman" that is, she has to be able to give informed consent. This, in turn, means that the consenting party must "have knowledge of the nature and extent of the harm associated with a termination of pregnancy; appreciate and understand the consequences of a termination of pregnancy; agree to undergo the termination of pregnancy; [and that] her agreement must be comprehensive and extend to all the consequences of the termination of pregnancy" (Mcquoid-Mason "Some Consent and Confidentiality Issues Regarding the Application of the Choice on Termination of Pregnancy Act to Girl-children" 2010 3(1) SAJBL 13).

The Children's Act provides for sufficient maturity and mental capability before children aged 12 years or older could independently consent to medical treatment or to surgery (with the consent of their parents or guardians). This, however, does not apply to terminations of pregnancy in terms of the Choice on Termination of Pregnancy Act (Mcquoid-Mason 2010 3(1) SAJBL 13). Thus the provisions relating to consent by children to medical treatment, as set out in the Children's Act, do not apply to the consent provisions in the Choice Act (Mcquoid-Mason 2010 3(1) SAJBL 13). This directly contradicts section 129(3) of the Children's Act, which provides that a 12-year old who seeks to have a surgical operation must be assisted by a parent or guardian. It is submitted that the termination of a pregnancy is a surgical operation, and thus the parent or guardian of the minor should be advised to further assist such a minor.

In contrast, the Choice Act does not require a parent or guardian to consent or to be consulted in relation to the termination of a minor's pregnancy. Instead, section 5(3) merely provides that a minor girl be advised to consult with her parent or guardian, or family member, or friend before the termination is carried out (should the girl minor decline to consult with the respective persons, the doctor cannot refuse to perform the termination). A termination can have long-term, negative, emotional, physical and physiological impacts on a woman and more so, on a minor girl. These effects to the wellbeing of the minor child, present and future, cannot be overlooked because the right to bodily and psychological integrity is a 
constitutional right. We consider that a child aged twelve years is insufficiently mature to be allowed such autonomy, and still needs parental guidance. We further submit that a child aged 12 years will not fully comprehend the impact of such a decision. Effectively, a minor child should not be allowed to have a termination, without the assistance of the parent or guardian concerned. The role of the parent or guardian is essential given the long-term impact of the termination. Thus, the Choice Act should be amended to be in line with the Children's Act especially section 129 of the Children's Act. There need to be proper regulations regarding the age of consent to termination of pregnancies.

\section{Cultural and religious male circumcision}

Section 12(8) of the Children's Act prohibits circumcision of male children under the age of 16, except when it is performed for religious purposes or for medical reasons, on the recommendation of a medical practitioner ( $\mathrm{s}$ 12(8)(a) and (b)). A circumcision performed for medical reasons may sound simple. The Act does not, however, give any guidelines regarding the concept of "medical reasons". The only internal indicator is a provision that it has to be "on the recommendation of medical practitioner" (s 12(8)(b)). Therefore, this provision could be abused by parents who may use medical practitioners to "rubber-stamp" their decision about the circumcision of their minor children. The authors submit that children should decide upon reaching adulthood whether they would be circumcised or not. No harm will be caused to a child if he is not circumcised, unless that is required for a genuine medical reason.

The other exception to the prescription of the Children's Act is that circumcision may be performed for religious reasons, in accordance with the practices of the religion concerned, and in the manner prescribed (s 12(8)(a) of the Act). On the face of it, this appears to have a general application. However, this provision may be problematic, as it has the potential to discriminate unfairly by preferring one religion over another. For example, there may be a thin line between religion and culture. Thus, the question may be whether this provision can be used for cultural or traditional circumcision. If not, the provision may not pass the test of constitutional validity (s 9 and 36 of the Constitution). Secondly, section 12(8)(a) of the Act may be seen as allowing parents to impose their religious convictions on their children, or to practise their religion using their children. Circumcision is a non-reversible condition. While parents may guide their children in religious matters and take them to church, circumcising them in the name of religion may be taking religion too far. This would hardly be in the child's best interests (see s 28(2) of the Constitution and s 9 of the Children's Act). Instead, children should be afforded an opportunity to decide whether to get circumcised or not, on religious grounds, when they are sufficiently mature in the same way as is the case in respect of cultural circumcision. This would accord with the situation when the child chooses to follow a different religion upon becoming an adult. 


\section{$9 \quad$ The new age of majority}

With effect from 1 July 2007, the age of majority was reduced from 21 to 18 years by the Children's Act, effectively repealing section 1 of the Age of Majority Act 57 of 1972 (see s 17 and 313 of the Children's Act). Unfortunately, the Children's Act had no transitional mechanisms in place. This has led to confusion about whether a minor fell under the jurisdiction of the Children's Act or the Age of Majority Act. Such was the case in APDOL v the Road Accident Fund (2013(2) SA 287 (GNP) (APDOL)). In casu there was much debate about whether a road-accident claim that had arisen while the plaintiff was a minor under the Age of Majority Act, had prescribed as a result of the coming into effect of the Children's Act on 1 July 2007. Thankfully, the High Court applied provisions of the Interpretation Act (33 of 1957, s 12(2)(c) and (e)) and sections 28 and 39(2) of the Constitution. It also relied on cases such as Minister of Public Works $v$ Haffejee NO (1996 (3) SA $745(A)$ ), to find for the minor. The same sentiments are echoed in The MEC for Education, KZN v Shange (2012 (5) SA 313 (SCA) par 4), where the court referred with approval to the court a quo's statement of the law. Therein the SCA held that: "a child whose cause of action arose before the commencement of $s 17$ of the Children's Act 38 of 2005 is still entitled to the same period of time in which to institute his or her claim for damages as he or she would have been, had the age of majority not been changed".

Nevertheless, with the new age of majority, minors lost statutory protection. For example, minors suddenly found themselves with contractual capacity that they would not have had under the Age of Majority Act. Moreover, the change of the age of majority has also affected the protection of minors in criminal proceedings. Whereas previously they would have been entitled to be tried in camera, they are now to be tried in open courts. This denies them the benefit that other child offenders would have had. Such exposure could have an adverse psychological effect on their well-being. Moreover, another important consequence of the change of the age of majority is with respect to child care. Suddenly, thousands of persons found themselves no longer entitled to benefits such as care and support.

\section{Conclusion}

Fragmentation of provisions in South African child law is evident in the various sources of law. Even various pieces of legislation that deal with a child's consent to marriage are filled with inconsistencies. There is no longer a place for such differentiations. In this regard, a restriction placed on intercourse in respect of adolescent couples, based on a two-year age gap between them, is unnecessary. There is also a need to harmonize the law dealing with the consent of minors to marriage, and other law in respect of children's matters. In view of the law that outlaws sexual intercourse with a minor below the age of 16 years, the legal age for consent to a civil marriage should be the age of 16 years. However, our view is that the Marriage Act should be aligned with the Customary Marriages Act and the Civil Union Act, so that the age for consent to marriage is 18 years. It amounts to unfair differential treatment of minors not to entertain this change. Moreover, the differential treatment between girls and boys in respect of consent to 
marriage and delictual accountability is unreasonable, and is not in the best interests of the child. It goes against the rising tide of opinion and law promoting the equality of the sexes.

Even though it would be sensible that the age when a minor will be rebuttably presumed to lack delictual accountability and criminal capacity should be harmonized to be set at 14 years as provided for by section $7(1)$ of the Child Justice Act, in respect of criminal responsibility, our view is that the age should be between 12-16 years, across the board. Effectively this would mean that anyone below the age of 12 years will be irrebuttably presumed to lack both criminal and delictual liability, instead of the current ages of seven and ten years for criminal and delictual liability, respectively. This will be in the best interests of the child, as it will be premised on maturity as opposed to puberty.

It is recommended that a review of the law be done by the South African Law Reform Commission to remove age discrepancies based on sex such as legal ages of permissible marriage for boys and girls. Other seemingly arbitrary age-limit variations should also be reviewed in order to harmonize them. Other sources of the law of the child in South Africa such as those dealing with health-related matters should also be revisited, and the law concerned should be reformed to bring it in line with logic and the best interests of the child.

RB Bernard and MC Buthelezi University of KwaZulu-Natal, Durban 